\title{
The Use of Proline in Screening for Tolerance to Drought and Salinity in Common Bean (Phaseolus vulgaris L.) Genotypes
}

\author{
Sugenith Arteaga ${ }^{1}$, Lourdes Yabor ${ }^{1,2}$, María José Díez ${ }^{3}$, Jaime Prohens ${ }^{3}{ }^{(}$, Monica Boscaiu ${ }^{4, *}$ \\ and Oscar Vicente ${ }^{3}$ (D) \\ 1 Institute for Plant Molecular and Cell Biology (IBMCP, UPV-CSIC), Universitat Politècnica de València, \\ Camino de Vera s/n, 46022 Valencia, Spain; suarcas@alumni.upv.es (S.A.); lyabor@bioplantas.cu (L.Y.) \\ 2 Permanent Address: Laboratory for Plant Breeding and Conservation of Genetic Resources, Bioplant Center, \\ University of Ciego de Avila, Ciego de Ávila 69450, Cuba \\ 3 Institute for the Conservation and Improvement of Valencian Agrodiversity (COMAV, UPV), \\ Universitat Politècnica de València, Camino de Vera s/n, 46022 Valencia, Spain; mdiezni@btc.upv.es (M.J.D.); \\ jprohens@btc.upv.es (J.P.); ovicente@upvnet.upv.es (O.V.) \\ 4 Mediterranean Agroforestry Institute (IAM, UPV), Universitat Politècnica de València, Camino de Vera s/n, \\ 46022 Valencia, Spain \\ * Correspondence: mobosnea@eaf.upv.es; Tel.: +34-963-879-253
}

Received: 30 April 2020; Accepted: 5 June 2020; Published: 9 June 2020

\begin{abstract}
The selection of stress-resistant cultivars, to be used in breeding programmes aimed at enhancing the drought and salt tolerance of our major crops, is an urgent need for agriculture in a climate change scenario. In the present study, the responses to water deficit and salt stress treatments, regarding growth inhibition and leaf proline (Pro) contents, were analysed in 47 Phaseolus vulgaris genotypes of different origins. A two-way analysis of variance (ANOVA), Pearson moment correlations and principal component analyses (PCAs) were performed on all measured traits, to assess the general responses to stress of the investigated genotypes. For most analysed growth variables and Pro, the effects of cultivar, treatment and their interactions were highly significant $(p<0.001)$; the root morphological traits, stem diameter and the number of leaves were mostly due to uncontrolled variation, whereas the variation of fresh weight and water content of stems and leaves was clearly induced by stress. Under our experimental conditions, the average effects of salt stress on plant growth were relatively weaker than those of water deficit. In both cases, however, growth inhibition was mostly reflected in the stress-induced reduction of fresh weight and water contents of stems and leaves. Pro, on the other hand, was the only variable showing a negative correlation with all growth parameters, but particularly with those of stems and leaves mentioned above, as indicated by the Pearson correlation coefficients and the loading plots of the PCAs. Therefore, in common beans, higher stress-induced accumulation of Pro is unequivocally associated with a stronger inhibition of growth; that is, with a higher sensitivity to stress of the corresponding cultivar. We propose the use of Pro as a suitable biochemical marker for simple, rapid, large-scale screenings of bean genotypes, to exclude the most sensitive, those accumulating higher Pro concentrations in response to water or salt stress treatments.
\end{abstract}

Keywords: abiotic stress biomarkers; bean landraces; osmolytes; plant breeding; salt stress; salt stress tolerance; water deficit; water stress tolerance 


\section{Introduction}

Drought and soil salinity are amongst the most restrictive environmental factors affecting agriculture worldwide. Even moderate degrees of water deficit or salt stress can lead to a reduction of $50-70 \%$ in average yields in most crops when compared with registered record yields [1-3]. Drought, brought about by the scarcity of rain, affects more than half of the agricultural land of our planet and is often linked to secondary salinisation of farmland due to intensive irrigation $[4,5]$. Cropland salinisation is becoming one of the major constrains for agriculture in many parts of the world, especially in arid and semi-arid regions. At the beginning of this century, it was estimated that around $20 \%$ of the irrigated lands were salinised [6], but this figure is increasing yearly, mainly due to anthropogenic alterations, such as irrigation with brackish water or the abusive and indiscriminate use of chemical fertilisers [4]. On the other hand, the scarcity of good-quality water for irrigation, mainly as a consequence of the effects of global warming, will mean more-significant crop losses in the near future, which will especially affect subsistence agriculture in developing countries [7]. Legumes are some of the most important crops, representing a significant component of the human diet. Globally, legumes complement cereal crops as the main sources of plant minerals and proteins [8]. Among the leguminous crops, Phaseolus L. is a large and diverse genus comprising about 70 American species [9], five of which have been domesticated (Phaseolus vulgaris L., Phaseolus dumosus Macfady, Phaseolus coccineus L., Phaseolus acutifolius A. Gray and Phaseolus lunatus L); moreover, a few additional species show signs of incipient domestication [10].

The common bean (P. vulgaris) is the most-consumed legume in human nutrition; it is an essential component of the diet, especially in developing countries, as a source of proteins, vitamins, minerals and fibre $[8,11]$. The species has a natural distribution area from northern Mexico to northwestern Argentina. It was domesticated independently in Central America and the Andes [12,13], but now it is cultivated practically all over the world. Beans from both origins were introduced to Spain in the 16th century [14-16], where they had to adapt to the new environmental conditions, which were very different from those in their native areas. The cropping system in small farms, spread in proximal areas, allowed the genetic flow between genotypes of Mesoamerican and Andean origin [17]. Due to centuries of bean cultivation, the Iberian Peninsula has become a secondary centre of diversification of this species [18].

Phaseolus vulgaris is not considered as very tolerant to water stress [19]; nevertheless, it is cultivated under diverse environmental conditions, including relatively dry areas [20,21]. In fact, globally, only a small percentage, around $7 \%$, of the cropland planted with common bean receives adequate rainfall [11], and in some areas, drought causes yield losses of up to $80 \%$ [22] Like practically all cultivated plants, the bean is a glycophyte, sensitive to soil salinity even at electric conductivity values below $2 \mathrm{dS} \cdot \mathrm{m}^{-1}$ [23]. However, just as there are cultivars that are more resistant to water stress, some respond better to high soil salinity [24,25].

As for other common crops, many bean genotypes no longer grown in the fields or cultivated only locally at a small scale (landraces, local varieties, heirlooms or minor commercial cultivars) are available from small farmers or germplasm banks and represent a rich source of genetic variability. Landraces appeared over time due to selection of traits specifically adapted to local conditions, often suboptimal or even highly stressful. Therefore, such genotypes are probably more competitive in low-input agriculture and represent a source of allelic richness that may enhance agronomic production under the foreseeable restrictive conditions imposed by climate change [26]. There is an increasing interest for the recovery of local landraces by consumers and markets, not only concerning global warming but also because of the commercial demand for local products, considered as tastier and healthier [27]. Unfortunately, many autochthonous varieties have been lost, and many others are at risk of extinction, due to genetic erosion. Screening this type of varieties for tolerance to stresses represents an interesting strategic path for the agriculture of the future.

The screening of a large number of genotypes would be greatly facilitated by identifying a suitable stress biomarker, easily quantified by simple, rapid and non-destructive assays, and unequivocally 
associated to the relative resistance of the cultivars to water deficit or salt stress. Proline (Pro), one of the commonest plant osmolytes [28,29], could be an appropriate candidate because a significant increase in Pro contents in response to water deficit, high salinity or other stressful conditions has been detected in beans-as in many other species. However, it is not yet clear whether Pro accumulation in P. vulgaris is associated with enhanced or reduced tolerance to stress since contradictory results are available in the literature. Some reports correlated higher Pro contents with a relatively higher stress tolerance when comparing different bean cultivars [30-37], whereas in other cases higher Pro concentrations were measured in the relatively more stress-sensitive cultivars [38-40]. All these studies were based on the comparison of a few genotypes. Only a wider analysis, based on a considerably higher number of cultivars, grown under the same experimental conditions and subjected to the same stress treatments, could establish whether responses to stress based on Pro accumulation are relevant, or not, for stress tolerance in P. vulgaris, and how Pro could be used as a reliable abiotic stress biomarker in this species.

Based on the ideas mentioned above, we have applied specific water deficit and salt stress treatments, under controlled greenhouse conditions, to a relatively large number of common bean cultivars, obtained from germplasm banks. The aims of this study were (i) to determine the overall response of the analysed genotypes to controlled water and salt stress treatments, (ii) to establish the role of Pro in bean stress responses, either as a mere stress biomarker or as an osmolyte directly involved on stress tolerance mechanisms and (iii) based on the results obtained, to propose Pro as a suitable biochemical marker for the rapid selection of bean cultivars with a (relatively) higher tolerance (or sensitivity) to drought or salinity.

\section{Materials and Methods}

\subsection{Plant Material}

The study included 47 accessions of common bean (P. vulgaris), from Spain (23), Colombia (19) and Cuba (5), provided by the Germplasm Bank of Universitat Politècnica de València (UPV), the International Center for Tropical Agriculture (CIAT) and the Bioplants Center, University of Ciego de Ávila, respectively.

Spanish genotypes are represented by local landraces, with geographic origins indicated in Table 1 . Materials from Cuba are commercial varieties or experimental lines from INIFAT (Alexander Humboldt Institute for Basic Research in Tropical Agriculture) or IIHDL (Liliana Dimitrova Horticultural Research Institute, La Habana, Cuba), and those from Colombia are lines reported to be relatively resistant to drought and high temperatures.

Table 1. Origin of the analysed Phaseolus vulgaris accessions and duration of the applied stress treatments.

\begin{tabular}{|c|c|c|c|c|c|}
\hline Abbreviation & Treatment (Weeks) & Genebank Code & Country & Origin & Cultivar Name \\
\hline Sp 1 & 2 & BGV000143 & Spain & Lecina, Huesca & Judía amarilla de enrame \\
\hline Sp 2 & 2 & BGV001191 & Spain & Velez Rubio, Almería & Judía \\
\hline Sp 3 & 2 & BGV001581 & Spain & Mercado el Olivar, Palma de Mallorca & Judia de careta \\
\hline Sp 4 & 2 & BGV003176 & Spain & Barlovento, Santa Cruz de Tenerife & Judia blanca mantecosa \\
\hline Sp 5 & 2 & BGV003616 & Spain & La Bañeza, León & \\
\hline Sp 6 & 2 & BGV003941 & Spain & AldeaNueva de Barbarroya, Toledo & Judía larguilla \\
\hline Sp 7 & 2 & BGV004159 & Spain & Plascencia, Cáceres & \\
\hline Sp 8 & 2 & BGV011254 & Spain & Las Presillas, Puente Viesgo, Cantabria & Garrafal oro \\
\hline Sp 9 & 2 & BGV013605 & Spain & Campo, Huesca & Negra \\
\hline Co 10 & 2 & INB-39 & Colombia & - & \\
\hline Co 11 & 2 & INB-40 & Colombia & - & \\
\hline Co 12 & 2 & INB-42 & Colombia & - & \\
\hline Co 13 & 2 & INB-43 & Colombia & - & \\
\hline Co 14 & 2 & INB-48 & Colombia & - & \\
\hline Co 15 & 2 & INB-48I & Colombia & - & \\
\hline $\mathrm{Cu} 16$ & 2 & $\mathrm{~V}-71$ & Cuba & INIFAT & Bolita $11^{\mathrm{a}}$ \\
\hline $\mathrm{Cu} 17$ & 2 & E-125 & Cuba & IIHLD & $\mathrm{E}-125^{\mathrm{b}}$ \\
\hline $\mathrm{Cu} 18$ & 2 & Milagro VIII & Cuba & INIFAT & Milagro Villareño $^{\text {a }}$ \\
\hline Sp 19 & 3 & BGV001167 & Spain & Chirivel, Almeria & Judia \\
\hline Sp 20 & 3 & BGV001169 & Spain & Laujar de Andarax, Almeria & Judia mocha \\
\hline Sp 21 & 3 & BGV001182 & Spain & Juviles, Granada & Alubias \\
\hline Sp 22 & 3 & BGV003610 & Spain & Ponferrada, León & \\
\hline
\end{tabular}


Table 1. Cont.

\begin{tabular}{|c|c|c|c|c|c|}
\hline Abbreviation & Treatment (Weeks) & Genebank Code & Country & Origin & Cultivar Name \\
\hline Sp 23 & 3 & BGV003614 & Spain & La Bañeza, León & \\
\hline Sp 24 & 3 & BGV003618 & Spain & La Bañeza, León & \\
\hline Sp 25 & 3 & BGV004161 & Spain & Plasencia, Cáceres & \\
\hline Sp 26 & 3 & BGV004466 & Spain & Bilbao, Vizcaya & Alubias pintas \\
\hline Sp 27 & 3 & BGV011235 & Spain & Beranga, Hazas de Cesto, Cantabria & Carica \\
\hline Sp 28 & 3 & BGV013603 & Spain & Beceite, Teruel & Judia de Franco \\
\hline Sp 29 & 3 & BGV013609 & Spain & Centenero, Huesca & Judia Fartapobres \\
\hline Sp 30 & 3 & BGV014980 & Spain & Alcorisa, Teruel & De tabilla ancha \\
\hline Sp 31 & 3 & BGV015856 & Spain & Alicante & Habichuela del barco \\
\hline Sp 32 & 3 & BGV015859 & Spain & Albarracín & Judia \\
\hline Co 33 & 3 & ALB-74 & Colombia & - & \\
\hline Co 34 & 3 & INB-35 & Colombia & - & \\
\hline Co 35 & 3 & INB-38 & Colombia & - & \\
\hline Co 36 & 3 & INB-41 & Colombia & - & \\
\hline Co 37 & 3 & INB-44 & Colombia & - & \\
\hline Co 38 & 3 & INB-45 & Colombia & - & \\
\hline Co 39 & 3 & INB-46 & Colombia & - & \\
\hline Co 40 & 3 & INB-47 & Colombia & - & \\
\hline Co 41 & 3 & SEF-9 & Colombia & - & \\
\hline Co 42 & 3 & SEF-52 & Colombia & - & \\
\hline Co 43 & 3 & SEF-53 & Colombia & - & \\
\hline Co 44 & 3 & SEF-55 & Colombia & - & \\
\hline Co 45 & 3 & SEF-56 & Colombia & - & \\
\hline $\mathrm{Cu} 46$ & 3 & V-13 & Cuba & INIFAT & P $2240^{\mathrm{b}}$ \\
\hline $\mathrm{Cu} 47$ & 3 & V-51 & Cuba & INIFAT & $\mathrm{P} 186^{\mathrm{b}}$ \\
\hline
\end{tabular}

a: commercial varieties; b: experimental lines.

\subsection{Plant Growth and Stress Treatments}

The plants were obtained by seed germination. Several seeds of each genotype were germinated in trays with peat, perlite and vermiculite (2:1:1). When the first trifoliate true leaves were formed, the seedlings were transplanted to individual 1.6 L-pots with the same substrate in the greenhouse; Hoagland's nutrient solution [41] was used for irrigation. When the plants reached a height of at least $20 \mathrm{~cm}$ and had two to five true leaves, plants were selected for the treatments and placed in $55 \times 40 \mathrm{~cm}$ plastic trays (10 pots per tray). Irrigation was performed twice a week by adding to each tray $1.5 \mathrm{~L}$ deionised water or a $150 \mathrm{mM} \mathrm{NaCl}$ solution, for the control and salt stress treatments, respectively. The water stress treatment was applied by completely withholding irrigation of the plants. Five individual plants (biological replicas) of each genotype were used per treatment. Treatments were stopped after two weeks for 18 genotypes when plants showed clear wilting and general decline symptoms in the water deficit treatment, but before plant mortality was observed; salt treatments of these cultivars were stopped at the same time. The remaining, relatively more resistant 29 genotypes were treated for an additional week. The two groups of plants were analysed independently. All treatments were carried out under controlled conditions in the greenhouse: long-day photoperiod ( $16 \mathrm{~h} \mathrm{of} \mathrm{light),}$ temperature set at $23{ }^{\circ} \mathrm{C}$ during the day and $17^{\circ} \mathrm{C}$ at night. Once the treatments were finished, whole plants were harvested, collecting separately their roots, stems and leaves. Several growth parameters were measured in all plants: the diameter of the stem (SD), the length of the roots (RL) and stems (SL), the number of trifoliate leaves (Lno) and the fresh weight of roots (RFW), stems (SFW) and leaves (LFW).

Part of the fresh material of roots, stems and leaves was weighed (FW), placed at $65^{\circ} \mathrm{C}$ in an oven for three days, and weighed again to determine the dry weight (DW). The water content percentage (WC\%) of the three organs was calculated according to the formula:

$$
\mathrm{WC}(\%)=[(\mathrm{FW}-\mathrm{DW}) / \mathrm{Fw}] \times 100
$$

\subsection{Quantification of Proline Contents}

Leaf Pro concentrations were quantified using dry plant material, according to the ninhydrin-acetic acid method [42]. Pro was extracted in a 3\% (w/v) aqueous sulfosalicylic acid solution; the sample was mixed with the acid ninhydrin solution, incubated for $1 \mathrm{~h}$ at $95{ }^{\circ} \mathrm{C}$, cooled on ice and extracted with toluene. Samples with known Pro amounts were assayed in parallel to obtain a standard curve. 
The absorbance of the supernatants was read at $520 \mathrm{~nm}$ using toluene as a blank. Pro concentration

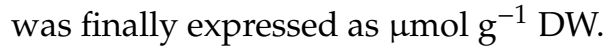

\subsection{Statistical Analysis}

Plants from the two- and three-week treatments were analysed separately. A two-way analysis of variance (ANOVA) was performed for all determined traits, to check the effects of the 'cultivar' and 'treatment' factors, and the interaction between treatment and genotype. Pearson moment correlations were also performed for all measured parameters, and a principal component analysis (PCA) was used to check the similarity between the responses to the different types of stress within each cultivar, and the similarity between accessions. Data were analysed using Statgraphics Centurion v.16 software (Statpoint Technologies, Warrenton, VA, USA).

\section{Results}

\subsection{Analysis of Variance of Registered Traits}

Some cultivars (18) were apparently more sensitive to both salt and water stress and therefore treatments were stopped after two weeks. For the remaining genotypes (29), treatments were extended to three weeks (Table 1). All growth parameters and the leaf Pro concentration of control and stressed plants, for each cultivar, are summarised in Supplementary Table S1. Notwithstanding quantitative differences between genotypes, the overall picture is that plants of most cultivars were affected by both types of stress, water deficit and salinity, which inhibited growth as indicated by the general relative reduction observed in the measured morphological variables. Under the specific stress conditions applied in the experiments, in most cases, growth inhibition was more accentuated in the water-stressed plants than in the salt-stressed ones. Again for most cultivars, leaf Pro contents increased significantly in response to both types of stress. To assess the general responses to stress of the selected cultivars, a two-way ANOVA was performed considering the effect on each parameter of cultivar and treatment, and their interaction (Table 2).

Table 2. Two-way analysis of variance (ANOVA) of cultivar, treatment and their interactions for the parameters considered. Numbers represent percentages of the sum of squares at the $5 \%$ confidence level. Abbreviations: RL, root length; RFW, root fresh weight; RWC, root water content; SD, stem diameter; SL, stem length; SFW, stem fresh weight; SWC, stem water content; Lno, leaf number; LFW, leaf fresh weight; LWC, leaf water content; Pro, proline content. Asterisks indicate the degree of significance: ${ }^{* *} p<0.01 ;{ }^{* * *} p<0.001$, ns $=$ not significant.

\begin{tabular}{ccccccccc}
\hline \multirow{2}{*}{ Trait } & \multicolumn{9}{c}{ Two Weeks } & \multicolumn{3}{c}{ Three Weeks } \\
\cline { 2 - 8 } & Cultivar & Treatment & Interaction & Residual & Cultivar & Treatment & Interaction Residual \\
\hline RL & $22.14^{* * *}$ & $18.42^{* * *}$ & $9.24^{\mathrm{ns}}$ & 50.19 & $32.90^{* * *}$ & $10.43^{* * *}$ & $21.52^{* * *}$ & 35.16 \\
RFW & $33.01^{* * *}$ & $17.20^{* * *}$ & $18.45^{* * *}$ & 31.34 & $24.88^{* * *}$ & $4.54^{* * *}$ & $15.05^{* *}$ & 55.53 \\
RWC & $4.34^{* * *}$ & $70.52^{* * *}$ & $14.75^{* * *}$ & 10.39 & $22.23^{* * *}$ & $52.05^{* * *}$ & $13.58^{* * *}$ & $12.15^{* *}$ \\
SD & $24.77^{* * *}$ & $27.08^{* * *}$ & $13.15^{* * *}$ & 35.00 & $14.17^{* * *}$ & $1.06^{* *}$ & $23.61^{* * *}$ & 61.16 \\
SL & $52.63^{* * *}$ & $11.77^{* * *}$ & $9.85^{* * *}$ & 25.76 & $42.71^{* * *}$ & $18.30^{* * *}$ & $18.17^{* * *}$ & 20.81 \\
SFW & $19.51^{* * *}$ & $47.29^{* * *}$ & $13.84^{* * *}$ & 19.36 & $26.50^{* * *}$ & $38.21^{* * *}$ & $15.10^{* * *}$ & 20.19 \\
SWC & $30.07^{* * *}$ & $33.12^{* * *}$ & $16.07^{* * *}$ & 20.74 & $31.64^{* * *}$ & $21.15^{* * *}$ & $32.13^{* * *}$ & 15.08 \\
Lno & $24.67^{* * *}$ & $32.12^{* * *}$ & $10.16^{* * *}$ & 33.05 & $14.69^{* * *}$ & $9.06^{* * *}$ & $21.14^{* * *}$ & 55.12 \\
LFW & $15.70^{* * *}$ & $53.55^{* * *}$ & $16.85^{* * *}$ & 13.89 & $32.54^{* * *}$ & $32.42^{* * *}$ & $23.8^{* * *}$ & 11.24 \\
LWC & $25.53^{* * *}$ & $37.59^{* * *}$ & $14.52^{* * *}$ & 22.36 & $32.50^{* * *}$ & $24.36^{* * *}$ & $20.21^{* * *}$ & 22.93 \\
Pro & $30.46^{* * *}$ & $28.92^{* * *}$ & $18.89^{* * *}$ & 21.72 & $40.52^{* * *}$ & $20.08^{* * *}$ & $15.61^{* * *}$ & 23.79 \\
\hline
\end{tabular}

For most analysed variables, the effects of cultivar, treatment and their interactions were highly significant $(p<0.001)$. The only non-significant value was found in the two-week treatment and the trait 'root length', for the interaction cultivar $\times$ treatment. In plants subjected to the two-week treatment, relatively stronger contributions to the sum of squares were those of 'cultivar' for the variables root fresh weight (RFW) and stem length (SL), and 'treatment' for root water content (RWC), stem fresh weight 
(SFW), leaf fresh weight (LFW) and leaf water content (LWC). For stem water content (SWC) and Pro, both factors, cultivar and treatment, contributed similarly to the sum of squares (SS). On the other hand, most of the variation observed for root length (RL), and stem diameter (SD) was due to uncontrolled variation, as shown by the higher SS percentage of the residual (Table 2).

The ANOVA of data obtained from the three-weeks-treated plants showed somewhat different results. The effect of 'cultivar' was the most substantial contributor to SS for the variables SL, LWC and Pro, and that of 'treatment' for RWC and SFW. The relative contributions of cultivar and treatment were similar for LFW, and those of cultivar and the interaction of both factors, for SWC. The most-significant contribution to variation of RL, RFW, SD and the number of leaves (Lno) is accounted for by the residual source of variation.

Disregarding the individual responses to water and salt stress of the selected bean genotypes, which vary quantitatively (Table S1), a general analysis was performed, including all cultivars and using the mean values calculated for all measured growth variables and Pro contents (Table 3). After the water stress treatments, either for two or three weeks, all morphological parameters determined in the stressed plants showed a significant decrease with respect to the corresponding values of the well-watered controls. The strongest reductions, down to less than 30\% of the controls, were observed for root and leaf fresh weight. The effect of water deficit was relatively weaker regarding the reduction of root length and stem parameters (SD, SL and SWC), especially in the three-week treatments. Leaf Pro concentration, on the contrary, significantly increased in response to water stress, about 2.7-fold and 2.1-fold, as average, for the plants treated for two and three weeks, respectively (Table 3).

Table 3. Mean values and percentages with respect to the control (\%) of traits measured in Phaseolus vulgaris cultivars after two and three weeks of control (C), water stress (WS) (withholding of irrigation) and salt stress (SS) (150 mM NaCl) treatments. Abbreviations: RL, root length; RFW, root fresh weight; RWC, root water content; SD, stem diameter; SL, stem length; SFW, stem fresh weight; SWC, stem water content; Lno, leaf number; LFW, leaf fresh weight; LWC, leaf water content; Pro, proline content. Different letters (lowercase for two-week and capital for three-week treatments) indicate significant differences between treatments for each trait, according to the Tukey test, at the $95 \%$ confidence level.

\begin{tabular}{|c|c|c|c|c|c|c|}
\hline \multirow{2}{*}{ Trait } & \multicolumn{3}{|c|}{ Two Weeks } & \multicolumn{3}{|c|}{ Three Weeks } \\
\hline & C & WS & SS & C & WS & SS \\
\hline $\mathrm{RL}(\mathrm{cm})$ & $36.04 c$ & $23.24 a$ & $30.39 b$ & $29.50 \mathrm{C}$ & $21.14 \mathrm{~A}$ & $25.73 \mathrm{~B}$ \\
\hline$\%$ & & 64.48 & 84.32 & & 71.66 & 87.22 \\
\hline RFW (g) & $3.22 \mathrm{~b}$ & $0.44 a$ & $3.36 \mathrm{~b}$ & $2.78 \mathrm{C}$ & $0.69 \mathrm{~A}$ & $1.85 \mathrm{~B}$ \\
\hline$\%$ & & 13.66 & 104.35 & & 24.82 & 66.55 \\
\hline RWC (\%) & $85.70 \mathrm{~b}$ & $31.94 a$ & $82.08 b$ & 84.07B & $42.11 \mathrm{~A}$ & $85.28 \mathrm{~B}$ \\
\hline$\%$ & & 37.27 & 95.78 & & 50.09 & 101.44 \\
\hline $\mathrm{SD}(\mathrm{mm})$ & $3.87 \mathrm{c}$ & $2.91 \mathrm{a}$ & $3.55 \mathrm{~b}$ & $3.89 \mathrm{C}$ & $3.18 \mathrm{~A}$ & $3.45 \mathrm{~B}$ \\
\hline$\%$ & & 75.19 & 91.73 & & 81.75 & 88.69 \\
\hline $\mathrm{SL}(\mathrm{cm})$ & $148.63 b$ & $109.95 a$ & $115.75 a$ & $139.90 \mathrm{~B}$ & $95.43 \mathrm{~A}$ & $90.85 \mathrm{~A}$ \\
\hline$\%$ & & 73.98 & 77.88 & & 68.21 & 64.94 \\
\hline SFW (g) & $10.40 \mathrm{c}$ & $2.82 \mathrm{a}$ & $5.37 \mathrm{~b}$ & $9.00 \mathrm{C}$ & $3.18 \mathrm{~A}$ & $4.63 \mathrm{~B}$ \\
\hline$\%$ & & 27.12 & 51.63 & & 35.33 & 51.44 \\
\hline SWC (\%) & $82.14 \mathrm{~b}$ & $56.84 a$ & $78.31 \mathrm{~b}$ & $82.82 \mathrm{~B}$ & $64.06 \mathrm{~A}$ & 79.47B \\
\hline$\%$ & & 69.20 & 95.34 & & 77.35 & 95.96 \\
\hline Lno & $12.43 b$ & $6.47 \mathrm{a}$ & $7.42 a$ & $13.28 \mathrm{~B}$ & $7.35 \mathrm{~A}$ & $7.98 \mathrm{~A}$ \\
\hline$\%$ & & 52.05 & 59.69 & & 55.35 & 60.09 \\
\hline LFW (g) & $22.73 c$ & $2.57 \mathrm{a}$ & $5.94 \mathrm{~b}$ & 18.21B & $4.08 \mathrm{~A}$ & $5.40 \mathrm{~A}$ \\
\hline$\%$ & & 11.31 & 26.13 & & 22.41 & 29.65 \\
\hline LWC & $84.04 c$ & $38.39 a$ & $58.58 b$ & $81.62 \mathrm{C}$ & $49.31 \mathrm{~A}$ & $55.48 \mathrm{~B}$ \\
\hline$\%$ & & 45.68 & 69.70 & & 60.41 & 67.97 \\
\hline Pro $\left(\mu \mathrm{mol} \mathrm{g}{ }^{-1} \mathrm{DW}\right)$ & $31.67 \mathrm{a}$ & $86.61 \mathrm{~b}$ & $82.74 \mathrm{~b}$ & $25.89 \mathrm{~A}$ & 53.57B & $68.29 \mathrm{C}$ \\
\hline$\%$ & & 273.48 & 261.26 & & 206.91 & 263.77 \\
\hline
\end{tabular}

Under the specific conditions of our experiments, salt stress had a smaller effect than water deficit on the average growth inhibition of the bean cultivars, reflected mostly in a sharp reduction 
$(>70 \%)$ of the leaf fresh weight with respect to the control, followed by that of stem fresh weight (about 50\%). Other parameters, such as root and stem water content, stem diameter or root fresh weight (in the two-week treatment) did not change significantly or decreased only slightly in response to increased salinity. The mean values calculated for most growth variables were similar for both treatment times. Pro contents also rose significantly, about 2.6 -fold over control values, in the salt-treated plants (Table 3).

\subsection{Correlation Analysis}

Pearson moment correlation between the analysed traits for salt and water stress are presented separately for plants from the two-week (Figure 1a) and three-week (Figure 1b) treatments. Correlations between all morphological variables were in most cases positive, for both stresses and the two treatment times, although the correlation coefficients varied widely, from $r<0.1$ to $r>0.9$. Considering specifically the two-week treatment, the strongest correlations $(r \geq 0.8)$ for the salt stress treatment were found between root water content (RWC) and stem fresh weight (SFW) or water content (SWC); or between SFW, leaf fresh weight (LFW) and the number of leaves (Lno) (Figure 1a). Under conditions of water stress, the strongest positive correlations were also found between SFW, LFW and Lno; between water contents of roots, stems and leaves (RWC/SWC/LWC) or between SFW and stem diameter (SD) (Figure 1a). On the other hand, Pro contents showed negative correlations with all growth parameters (except for RWC in the salt stress treatment), most significantly with leaf water content, but also with LFW and stem growth parameters (SFW and SWC). Correlations followed a similar pattern for both types of stress but were weaker (lower ' $r$ ' values) in the case of salt stress (Figure 1a).

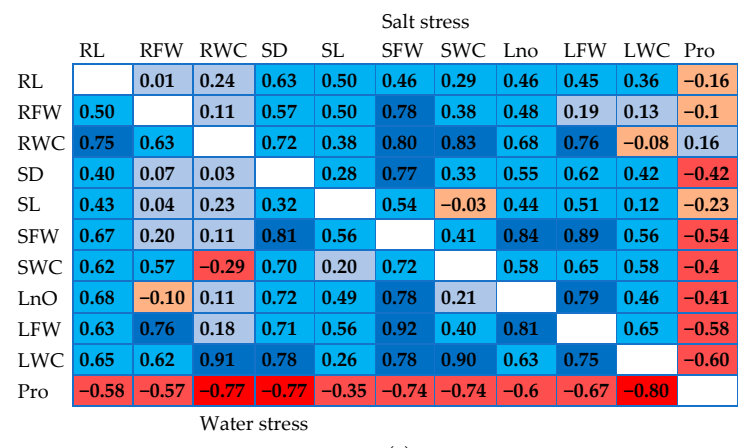

(a)

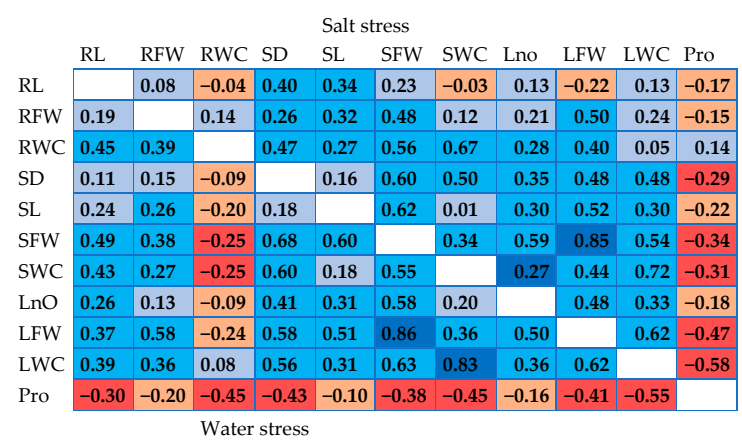

(b)

Figure 1. Heatmap of Pearson moment correlation coefficients $(\mathrm{r})$ between the analysed traits in Phaseolus vulgaris cultivars submitted to two weeks (a) and three weeks (b) of water and salt stresses. Dark blue denotes high correlation $(r \rightarrow 1)$, dark red high negative correlation $(r \rightarrow-1)$. Abbreviations: $\mathrm{RL}$, root length; RFW, root fresh weight; RWC, root water content; SD, stem diameter; SL, stem length; SFW, stem fresh weight; SWC, stem water content; Lno, leaf number; LFW, leaf fresh weight; LWC, leaf water content; Pro, proline content. 
Correlations between the different measured variables, generally positive for growth parameters and negative between Pro contents and the rest of variables, were maintained, qualitatively, when comparing the two- and three-week treatments, and for both stresses, but with lower relative significance for the longer treatment time (Figure 1b).

\subsection{Principal Component Analysis (PCA)}

A PCA was performed, separately for the cultivars subjected to the two-week and three-week treatments, and including the mean values of all measured parameters and the three applied conditions (control, water stress and salt stress) (Table 4, Figure 2).

Table 4. Component weights in the PCA performed on cultivars subjected to two and three weeks of treatment. Abbreviations: RL, root length; RFW, root fresh weight; RWC, root water content; SD, stem diameter; SL, stem length; SFW, stem fresh weight; SWC, stem water content; Lno, leaf number; LFW, leaf fresh weight; LWC, leaf water content; Pro, proline.

\begin{tabular}{ccccc}
\hline Trait & Two Weeks & \multicolumn{3}{c}{ Three Weeks } \\
\hline & Component $\mathbf{1}$ & Component 2 & Component 1 & Component 2 \\
\hline RL & 0.320 & -0.054 & 0.243 & 0.109 \\
RFW & 0.222 & 0.329 & 0.282 & -0.017 \\
RWC & 0.318 & 0.267 & 0.250 & 0.529 \\
SL & 0.201 & -0.578 & 0.262 & -0.470 \\
SFW & 0.388 & -0.178 & 0.421 & -0.217 \\
SWC & 0.325 & 0.436 & 0.319 & 0.491 \\
Lno & 0.322 & -0.374 & 0.286 & -0.282 \\
LFW & 0.370 & -0.227 & 0.406 & -0.264 \\
LWC & 0.354 & 0.260 & 0.384 & 0.218 \\
Pro & -0.291 & -0.053 & -0.240 & -0.030 \\
\hline
\end{tabular}

The PCA corresponding to the two-week treatments detected two components with Eigenvalues higher than 1 , which explained $70.1 \%$ of the total variability of data $(56.5 \%$ and $13.6 \%$ for the first and second components, respectively). All growth parameters-most significantly the fresh weights of stems (SFW) and leaves (LFW), followed by the water contents of both organs (LWC and SWC)-were positively correlated with the first component, whereas the only one negatively correlated was Pro concentration in leaves. Regarding the second component, some morphological variables (especially SWC and RFW) were positively correlated, whereas for others (e.g., SL or Lno) the correlation was negative (Table 4, Figure 2a).

Two components with an Eigenvalue higher than one were also detected in the PCA corresponding to the three-week treatments, the first explaining $44.3 \%$ and the second $14.0 \%$ of the total variability; that is, together explaining $58.3 \%$ of the total variation. Correlations of the different variables followed similar patterns to those observed for the cultivars treated for two weeks, for example regarding the negative correlation of Pro with the first component, and the positive correlations of all growth variables, with SFW and LFW showing the highest significance (Table 4, Figure 2b).

The 18 cultivars from the shorter treatment period (Figure 3a) were dispersed onto the two axes of the scatterplot, indicating high variability in the selected genotypes. There was, however, good separation between the different treatments, not only when looking individually at each cultivar, but also considering the overall behaviour of all genotypes. Plants from the control (green symbols) and water stress (pink) treatments were clearly separated, with almost no overlapping between the two conditions. Those symbols (blue) corresponding to the salt stress treatments appear located in the scatterplot in-between the control and water stress samples, which was in agreement with the weaker effect (on average) of the salt treatments as compared to water deficit, under the specific conditions used in our experiments. The scatterplot corresponding to the 29 cultivars that were subjected to the more prolonged (three-week) treatment (Figure 3b) showed the same general picture, 
maybe with more overlapping of the water- and salt-stressed plants. More-significant dispersion of the scores was found, for both treatment times, in the controls indicating a high variability of morphological traits of the different cultivars. Under salt stress, the separation between scores was not so pronounced as under water stress, suggesting a more homogeneous general response of the bean genotypes to salinity than to drought, at least under the conditions of our experiments (Figure 3).

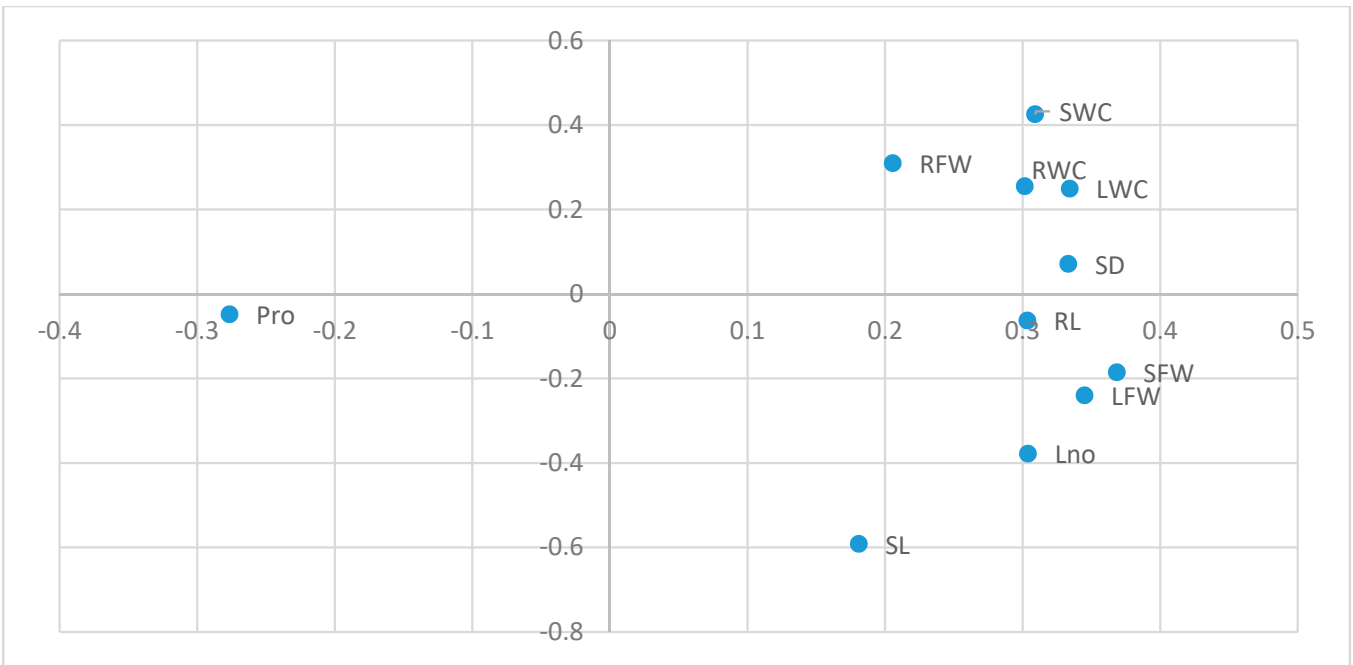

(a)

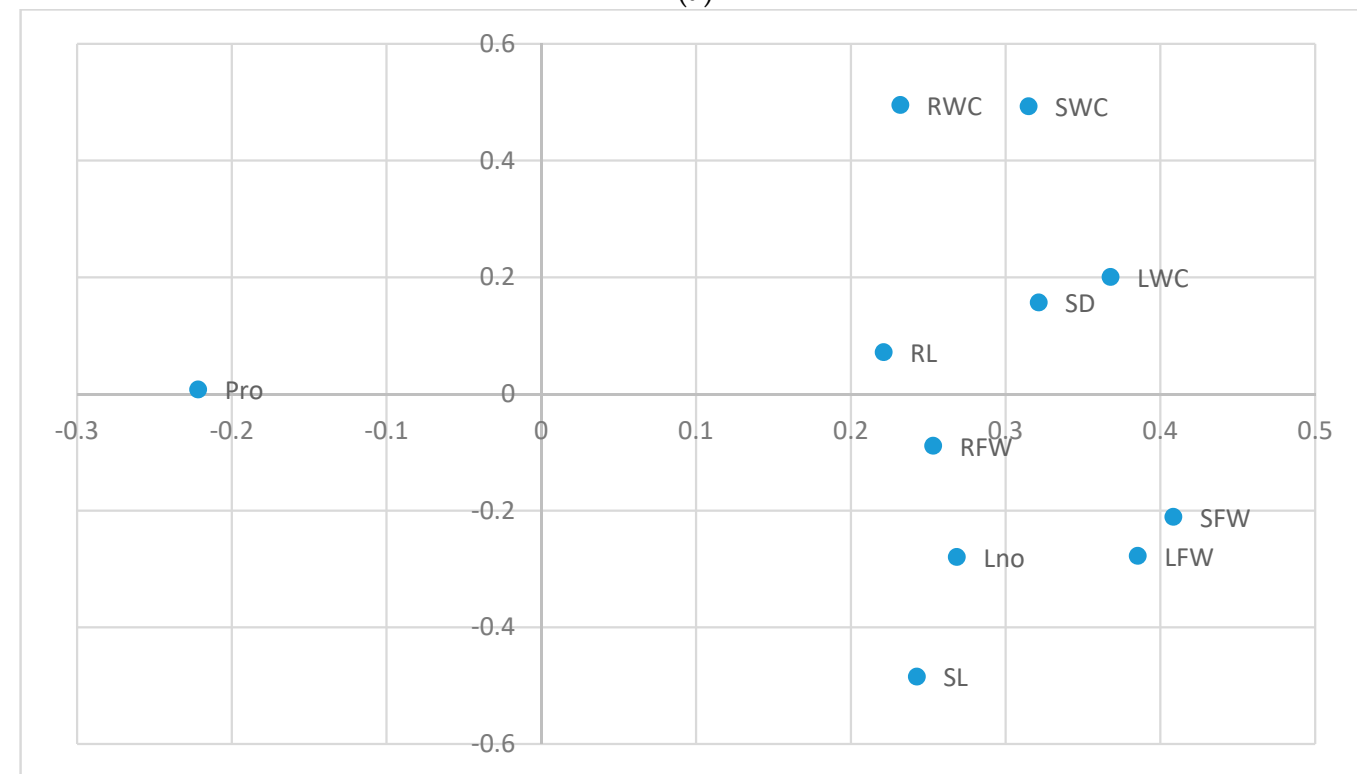

(b)

Figure 2. Loading plot of the principal component analysis (PCA) conducted with the analysed traits, in P. vulgaris cultivars subjected to control, water deficit and salt stress treatments. Two-week treatments (a); $56.5 \%$ and $13.6 \%$ of the total variability are explained by the first ( $x$-axis) and the second (y-axis) components, respectively. Three-week treatments (b); $44.3 \%$ and $14.0 \%$ of the total variability are explained by the first ( $x$-axis) and the second ( $y$-axis) components, respectively. Abbreviations: RL, root length; RFW, root fresh weight; RWC, root water content; SD, stem diameter; SL, stem length; SFW, stem fresh weight; SWC, stem water content; Lno, leaf number; LFW, leaf fresh weight; LWC, leaf water content; Pro, proline. 


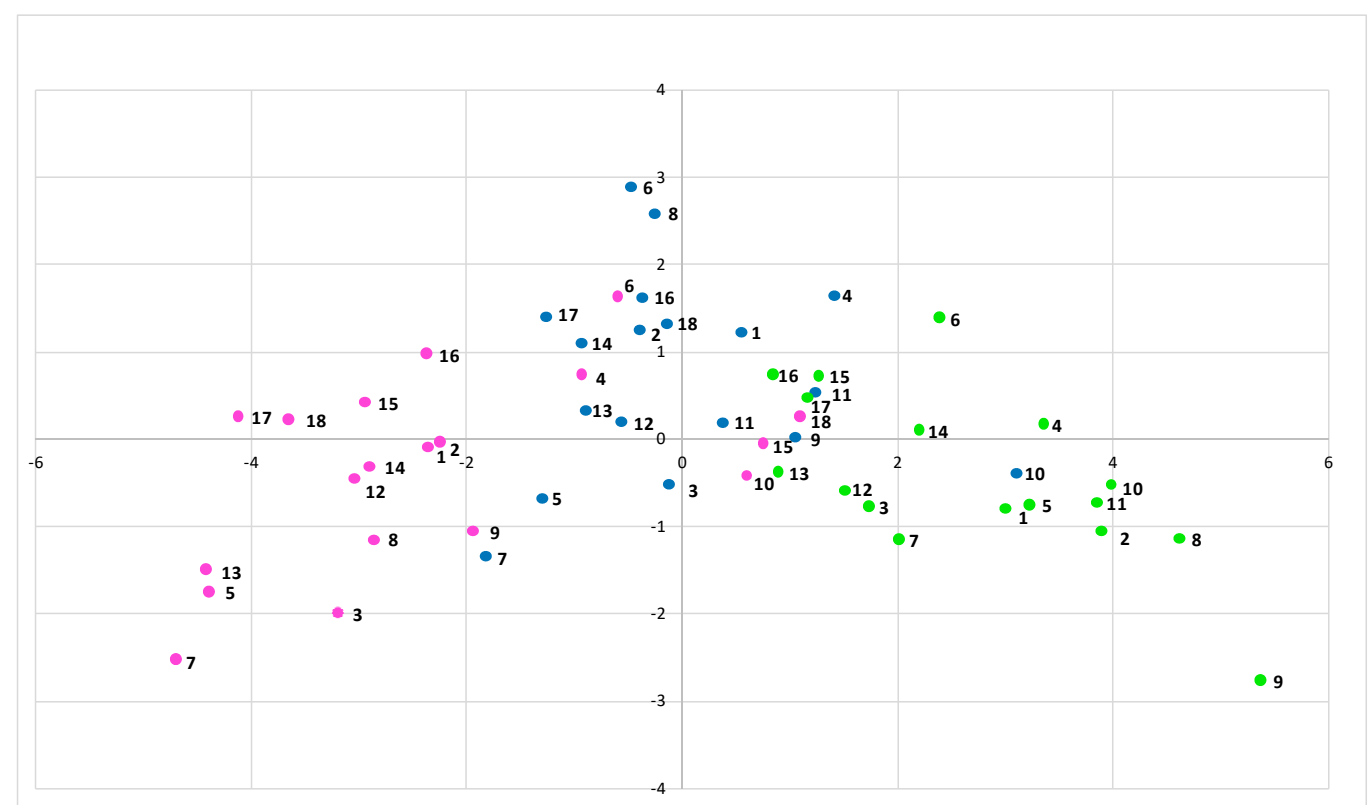

(a)

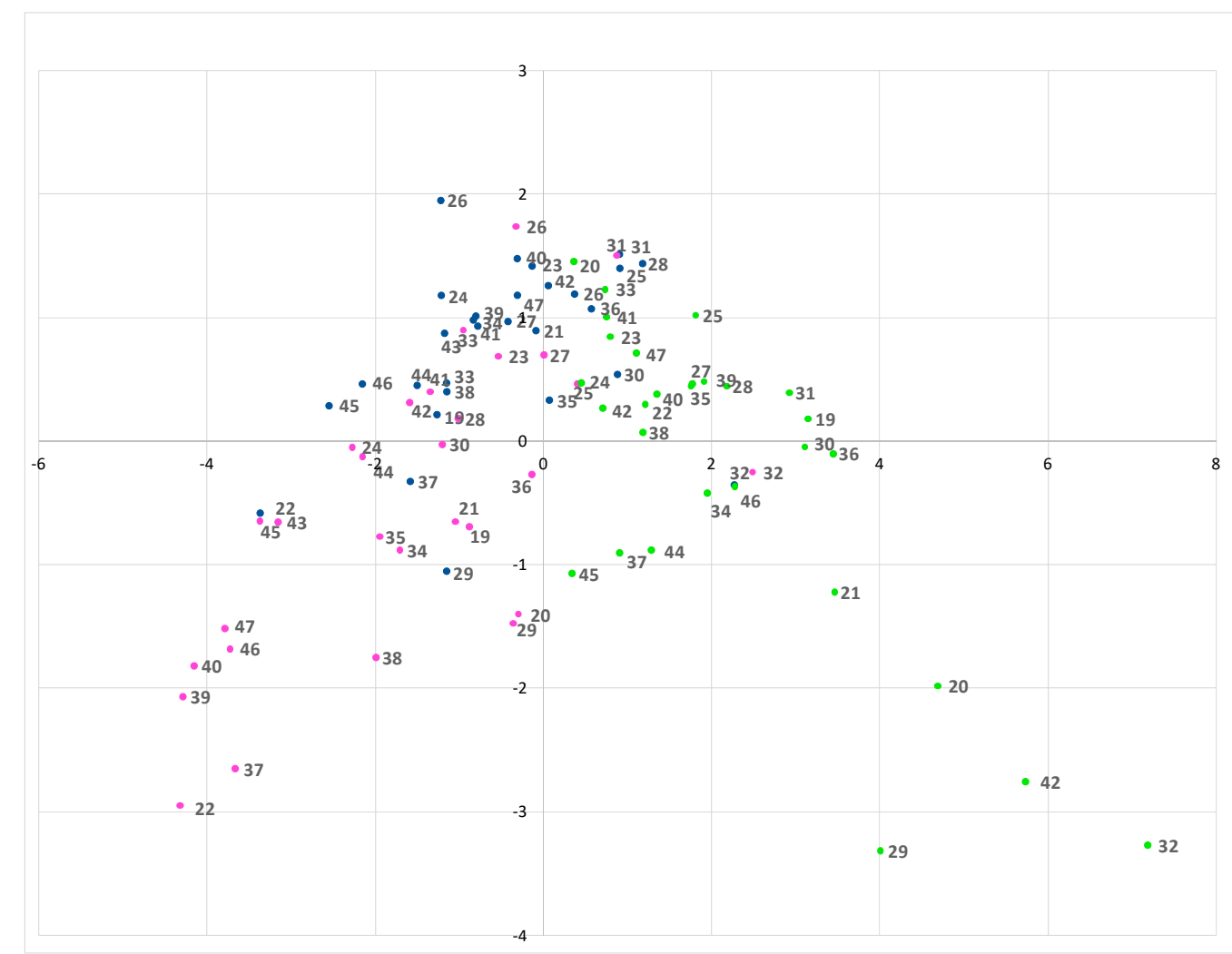

(b)

Figure 3. Scatter plot of the PCA scores. Plants treated for two (a) or three weeks (b); control (green), water deficit (pink) and salt stress (blue) treatments. (a) 1-9, cultivars from Spain; 10-15, from Colombia and 16-18, from Cuba and (b) 19-32, cultivars from Spain; 33-45, from Colombia and 46 and 47 from Cuba.

Based on the PCA scatter plot in the two-week trial (Figure 3a), we identified four accessions $(7,5,13$ and 17$)$ with highly negative values for the first component (i.e., with high concentrations of Pro and low values for growth and water content parameters), both for the water deficit and salinity treatments; these cultivars can be considered as highly susceptible to both stresses. On the other hand, 
three accessions $(25,31$ and 32) were detected in the three-week scatter plot (Figure 3b), showing positive values for the first component (low Pro contents and limited growth inhibition), both for the drought and salt stress treatments, indicating that these accessions can be considered as the most tolerant to both stresses. Similarly, the relative position of other accessions along the $x$-axis should allow a ranking of their tolerance to water deficit and to salinity, within each group of cultivars (treated for two or three weeks).

\section{Discussion}

In the present study, responses to drought and salinity have been analysed in 47 Phaseolus vulgaris genotypes of different origins. Large variability was observed in the size and morphology of the plants of the different bean cultivars-as seen when comparing their growth parameters (Supplementary Table S1) individually and also by their dispersion in the PCA scatterplots (Figure 3)-making it difficult to determine, at first sight, the variables that are more relevant for assessing the relative degree of stress-induced growth inhibition and, therefore, for ranking the different cultivars according to their relative sensitivity or resistance to water deficit and salt stress. However, the statistical analyses performed with all experimental data provided a clear overall picture of the responses to stress of the P. vulgaris cultivars. Both 'cultivar' and 'treatment', as well as their interaction, had a highly-significant effect on (practically) all growth traits analysed, and on Pro contents, for the twoand three-week treatments of both water deficit and salt stress. In all cases, growth inhibition was mostly reflected in the stress-induced reduction of fresh weight and water contents of stems (SFW and SWC) and leaves (LFW and LWC), as reported in the same species [39,40] or other species of this genus [43]. These parameters are the growth variables most significantly correlated, positively, with the first principal component in the PCA. Pro, on the other hand, was the only variable showing a negative correlation with all growth variables, but particularly with those of stems and leaves mentioned above-as indicated by the Pearson correlation coefficients and the loading plots of the PCAs.

When comparing the stress tolerance of related taxa, for example, different cultivars of a particular crop, measurements of growth parameters are often complemented with the determination of several biochemical stress markers, associated with increased (or lower) tolerance; they include compatible solutes or osmolytes [44-47]. Proline (Pro) is a common osmolyte in plants, which accumulates in response to different types of abiotic stress, including drought and salinity, in a variety of plant species [28,48-50]. Besides its role in cellular osmotic adjustment, Pro has additional functions as 'osmoprotectant'; it directly stabilises sub-cellular structures, such as membranes and proteins, scavenges free radicals buffering redox potential, alleviates cellular acidosis and acts as a signalling molecule in the responses to stress [51,52]. Proline also plays essential roles in the absence of stress, being involved in many developmental processes; for example, Pro concentration increases during pollen and seed maturation. However, Pro can be toxic for certain tissues if it is partially catabolised to pyrroline-5-carboxylate (P5C), leading to apoptosis [53]. Considering the multiple functions of Pro, it is logical to assume that Pro accumulation would be associated with higher stress tolerance, and this has indeed been demonstrated for many plants, both wild species $[54,55]$ and crops $[43,56]$. However, other comparative studies on related taxa, such as species of the same genus or cultivars or varieties of the same species, revealed higher Pro accumulation under stress in the less-tolerant genotypes $[57,58]$. There is some confusion, often found in the literature, between the concepts of 'stress responses' and 'stress tolerance'. Even though stress tolerance mechanisms are based on specific stress responses, not all responses are relevant for tolerance. On this line, Pro accumulation can be considered as a general 'response' to abiotic stress in many plant species, but Pro may or may not be involved in stress tolerance mechanisms, depending on the species.

Common bean is clearly a Pro accumulator species, as numerous reports have shown significant increases in Pro contents in Phaseolus plants in response to either salt stress $[38,39,59]$ or water stress $[40,60,61]$ treatments. Also, Pro appears to be a good bioindicator in other types of stress in beans, such as that induced by excess nitrogen dosage [62], herbicides [63] or heavy metals [64]. 
Moreover, exogenous application of Pro was shown to alleviate the salt stress deleterious effects in beans [65]. However, there are some contradictory data in the literature regarding the function of Pro in the mechanisms of stress tolerance in Phaseolus. Some published reports indicated higher Pro contents in more drought-tolerant [30,34-37] or salt-tolerant [31-33] cultivars than in less tolerant ones; that is, Pro accumulation correlates positively with the degree of stress resistance, suggesting a direct contribution to stress tolerance mechanisms. Other reports, on the contrary, showed that, under stress conditions, the less tolerant genotypes had a higher concentration of this osmolyte than the more resistant cultivars [38-40,66]; therefore, in this case, Pro is simply a marker of the level of stress affecting the plants, accumulating at higher concentrations in the more stressed-the more sensitive-cultivars, but is not directly involved in the mechanisms of tolerance. This was also the conclusion of previous work from our laboratory, comparing three commercial cultivars (two of P. vulgaris and one of P. coccineus) and one Spanish common bean landrace $[39,40]$. All these latter studies, based on the comparison of a few bean genotypes, generally some commercial cultivars, have been confirmed in the present work, using a much larger number of cultivars of different origins and an extensive statistical analysis of the experimental data.

Our results showed a strong negative correlation of Pro levels and growth variables, especially the fresh weight and water content of the aboveground organs of the plants; these are the most relevant parameters to evaluate the inhibition of growth induced under water deficit and high salinity conditions. Therefore, there is an unequivocal association of higher Pro contents with stronger growth inhibition; that is, with a higher sensitivity to stress of the bean cultivars.

\section{Conclusions}

Phaseolus vulgaris cannot be considered as drought- or salt-tolerant. It is even more sensitive to stress than many other crops such as barley or cowpea $[67,68]$. However, amongst the extremely high number of available genotypes of $P$. vulgaris, some will show a relatively higher resistance and could be used as parental lines in bean breeding programmes aimed at enhancing stress tolerance in this major crop. The identification of common bean accessions in the extremes of variation for susceptibility and tolerance to water deficit and salinity is of great interest for further studies on the physiological mechanisms of tolerance to both stresses. Also, the development of segregating generations after hybridisation between both types of materials can lead to the identification of genomic regions involved in tolerance to these stresses.

Proline concentrations in stressed plants can be determined by a simple and rapid spectrophotometric assay, requiring only small amounts of leaf material. From a practical point of view, our results support the use of Pro as a biochemical marker for the initial, large-scale screening of bean cultivars, to exclude the most sensitive, those accumulating higher Pro concentrations in response to water or salt stress.

Supplementary Materials: The following are available online at http://www.mdpi.com/2073-4395/10/6/817/s1, Table S1: Variation of morphological parameters and proline concentrations in 47 accessions of common bean (Phaseolus vulgaris) under salt stress and water stress.

Author Contributions: Conceptualization, M.B. and O.V.; methodology, S.A. and L.Y.; software, J.P.; validation, M.J.D. and J.P.; formal analysis, L.Y.; investigation, S.A. and L.Y.; resources, O.V.; data curation, S.A.; writing - original draft preparation, S.A. and M.B.; writing-review and editing, M.J.D., J.P. and O.V.; visualization, S.A.; supervision, M.B. and O.V.; project administration, M.B. and O.V.; funding acquisition, O.V. All authors have read and agreed to the published version of the manuscript.

Funding: This research received no external funding.

Acknowledgments: We are indebted to Steve Beebe, from Alliance Biodiversity CIAT, for providing the Colombian bean cultivars and for his helpful comments on the manuscript.

Conflicts of Interest: The authors declare no conflict of interest. 


\section{References}

1. Mantri, N.; Patade, V.; Penna, S.; Ford, R.; Pang, E. Abiotic stress responses in plants: Present and future. In Abiotic Stress Responses in Plants: Metabolism, Productivity and Sustainability; Ahmad, P., Prasad, M.N.V., Eds.; Springer: New York, NY, USA, 2012; pp. 1-19. [CrossRef]

2. Zörb, C.; Geilfus, C.-M.; Dietz, K.J. Salinity and crop yield. Plant Biol. 2019, 21, 31-38. [CrossRef]

3. Osakabe, Y.; Osakabe, K.; Shinozaki, K.; Tran, L. Response of plants to water stress. Front. Plant Sci. 2014, 5, 86. [CrossRef] [PubMed]

4. Fita, A.; Rodríguez-Burruezo, A.; Boscaiu, M.; Prohens, J.; Vicente, O. Breeding and domesticating crops adapted to drought and salinity: A new paradigm for increasing food production. Front. Plant Sci. 2015, 6, 978. [CrossRef] [PubMed]

5. Shahid, S.A.; Zaman, M.; Heng, L. Soil salinity: Historical perspectives and a world overview of the problem. In Guideline for Salinity Assessment, Mitigation and Adaptation Using Nuclear and Related Techniques; Zaman, M., Shahid, S.A., Eds.; Springer: Cham, Switzerland, 2018; pp. 43-53. [CrossRef]

6. Flowers, T.; Flowers, S. Why does salinity pose such a difficult problem for plant breeders? Agric. Water Manag. 2005, 78, 15-24. [CrossRef]

7. Morton, J.F. The impact of climate change on smallholder and subsistence agriculture. Proc. Natl. Acad. Sci. USA 2007, 104, 19680-19685. [CrossRef]

8. Bellucci, E.; Bitocchi, E.; Rau, D.; Rodriguez, M.; Biagetti, E.; Giardini, A.; Attene, G.; Nanni, L.; Papa, R. Genomics of origin, domestication and evolution of Phaseolus vulgaris. In Genomics of Plant Genetics Resources; Tuberosa, R., Graner, A., Frison, E., Eds.; Springer: Dordrecht, The Netherlands, 2014; pp. 483-507. [CrossRef]

9. Freytag, G.F.; Debouck, D.G. Taxonomy, Distribution, and Ecology of the genus Phaseolus (Leguminosae-Papilionoideae) in North America, Mexico and Central America; Botanical Research Institute of Texas (BRIT): Forth Worth, TX, USA, 2002; pp. 1-298.

10. Delgado-Salinas, A.; Bibler, R.; Lavin, M. Phylogeny of the genus Phaseolus (Leguminosae): A recent diversification in an ancient landscape. Syst. Bot. 2006, 31, 779-791. [CrossRef]

11. Broughton, W.J.; Hernández, G.; Blair, M.; Beebe, S.; Gepts, P.; Vanderleyden, J. Beans (Phaseolus spp.)—Model food legumes. Plant Soil 2003, 252, 55-128. [CrossRef]

12. Gepts, P.; Debouck, D.G. Origin, domestication, and evolution of the common bean, Phaseolus vulgaris. In Common Beans: Research for Crop Improvement; van Schoonhoven, A., Voysest, O., Eds.; Cab Intern: Wallingford, UK, 1991; pp. 7-53.

13. Rendón-Anaya, M.; Montero-Vargas, J.M.; Saburido-Álvarez, S.; Vlasova, A.; Capella-Gutierrez, S.; Ordaz-Ortiz, J.J.; Aguilar, O.M.; Vianello-Brondani, R.P.; Santalla, M.; Delaye, L.; et al. Genomic history of the origin and domestication of common bean unveils its closest sister species. Genome Biol. 2017, 18, 60. [CrossRef]

14. Ortwin-Sauer, C. The Early Spanish Men; University of California Press: Berkeley, CA, USA, 1966.

15. Brucher, O.B.; Brucher, H. The South American wild bean (Phaseolus aborigeneus Burk.) as ancestor of the common bean. Econ. Bot. 1976, 30, 257-272. [CrossRef]

16. Debouck, D.G.; Smartt, J. Bean. In Evolution of Crop Plants, 2nd ed.; Smartt, J., Simmonds, N.W., Eds.; Longman Scientific and Technical: Harlow, UK, 1995; pp. 287-296.

17. Arteaga, S.; Yabor, L.; Torres, J.; Solbes, E.; Muñoz, E.; Díez, M.J.; Vicente, O.; Boscaiu, M. Morphological and agronomic characterization of Spanish landraces of Phaseolus vulgaris L. Agriculture 2019, 9, 149. [CrossRef]

18. Pinheiro, C.; Baeta, J.P.; Pereira, A.M.; Dominguez, H.; Ricardo, C. Mineral elements correlations in a Portuguese germplasm collection of Phaseolus vulgaris. Integrating Legume Biology for sustainable Agriculture. In Proceedings of the 6th European Conference on Grain Legumes, Lisbon, Portugal, 12-16 November 2007; pp. 125-126.

19. Molina, J.; Moda-Cirino, V.; Da Silva Fonseca, N.J.; Faria, R.; Destro, D. Response of common bean cultivars and lines to water stress. Crop Breed. Appl. Biotechnol. 2001, 1. [CrossRef]

20. Graham, P.; Ranalli, P. Common bean (Phaseolus vulgaris L.). Field Crop Res. 1997, 53, 131-146. [CrossRef]

21. Singh, S.P. Drought resistance in the race Durango dry bean landraces and cultivars. Agron. J. 2007, 99, 1219-1225. [CrossRef] 
22. Cuellar-Ortiz, S.; Arrieta-Montiel, M.; Acosta-Gallegos, J.; Covar-Rubias, A. Relationship between carbohydrate partitioning and drought resistance in common bean. Plant Cell Environ. 2008, 31, 1399-1409. [CrossRef]

23. Maas, E.; Hoffman, G. Crop salt tolerance-current assessment. J. Irrig. Drain. Eng. 1977, 103, 115-134.

24. Gama, P.; Inanaga, S.; Tanaka, K.; Nakazawa, R. Physiological response of common bean (Phaseolus vulgaris L.) seedlings to salinity stress. Afr. J. Biotechnol. 2007, 6, 79-88.

25. Zhumabayeva, B.A.; Biotechnology, K.A.; Aytasheva, Z.G.; Dzhangalina, E.D.; Esen, A.; Lebedeva, L.P. Screening of domestic common bean cultivar for salt tolerance during in vitro cell cultivation. Int. J. Biol. 2019, 12, 94-102. [CrossRef]

26. Fess, T.L.; Kotcon, J.B.; Benedito, V.A. Crop breeding for low input agriculture: A sustainable response to feed a growing world population. Sustainability 2011, 3, 1742-1772. [CrossRef]

27. Hurtado, M.; Vilanova, S.; Plazas, M.; Gramazio, P.; Andújar, I.; Herraiz, F.J.; Prohens, J. Enhancing conservation and use of local vegetable landraces: The Almagro eggplant (Solanum melongena L.) case study. Genet. Resour. Crop Evol. 2014, 61, 787-795. [CrossRef]

28. Szabados, L.; Savouré, A. Proline: A multifunctional amino acid. Trends Plant Sci. 2010, 15, 89-97. [CrossRef]

29. Verslues, P.E.; Sharma, S. Proline metabolism and its implications for plant-environment interaction. Arabidopsis Book 2010, 8, e0140. [CrossRef] [PubMed]

30. Kapuya, J.A.; Barendse, G.W.M.; Linskens, H.F. Water stress tolerance and proline accumulation in Phaseolus vulgaris L. Acta Bot. Neerl. 1985, 34, 293-300. [CrossRef]

31. Misra, N.; Gupta, A.K. Effect of salt stress on proline metabolism in two high yielding genotypes of green gram. Plant Sci. 2005, 169, 331-339. [CrossRef]

32. Cárdenas-Avila, M.; Verde-Star, J.; Maiti, R.; Foroughbakhch, R.; Gámez-González, H.; Martínez-Lozano, S.; Núñez-González, M.; García Díaz, G.; Hernández-Piñero, J.; Morales-Vallarta, M. Variability in accumulation of free proline on in vitro calli of four bean (Phaseolus vulgaris L.) cultivars exposed to salinity and induced moisture stress. Phyton 2006, 75, 103-108.

33. Kaymakonova, M.; Stoeva, N. Physiological responses of bean plants (Phaseolus vulg. L.) to salt stress. Gen. Appl. Plant Physiol. 2008, 34, 177-188.

34. Herrera Flores, T.S.; Ortíz Cereceres, J.; Delgado Alvarado, A.; Acosta Galleros, J.A. Growth and, proline and carbohydrate content of bean seedlings subjected to drought stress. Rev. Mexicana Cienc. Agric. 2012, 3 , 713-725.

35. Ghanbari, A.A.; Mousavi, S.H.; Mousapou Gorji, A.; Rao, I. Effects of water stress on leaves and seeds of bean (Phaseolus vulgaris L.). Turk. J. Field Crops 2013, 18, 73-77.

36. Kusvuran, S.; Dasgan, H.Y. Effects of drought stress on physiological and biochemical changes in Phaseolus vulgaris L. Legume Res. 2017, 40, 55-62.

37. Wang, Q.; Ang, Q.; Lin, F.; Wei, S.H.; Meng, X.X.; Yin, Z.G.; Guo, Y.F.; Yang, G.D. Effects of drought stress on endogenous hormones and osmotic regulatory substances of common bean (Phaseolus vulgaris L.) at seedling stage. Appl. Ecol. Environ. Res. 2019, 17, 4447-4457. [CrossRef]

38. Jiménez-Bremont, J.F.; Becerra-Flora, A.; Hernández-Lucero, E.; Rodríguez-Kessler, M.; Acosta-Gallegos, J.; Ramírez Pimentel, J. Proline accumulation in two bean cultivars under salt stress and the effect of polyamines and ornithine. Biol. Plant. 2006, 50, 763-766. [CrossRef]

39. Al Hassan, M.; Morosan, M.; López-Gresa, M.P.; Prohens, J.; Vicente, O.; Boscaiu, M. Salinity-induced variation in biochemical markers provides insight into the mechanisms of salt tolerance in common (Phaseolus vulgaris) and runner (P. coccineus) beans. Int. J. Mol. Sci. 2016, 17, 1582. [CrossRef] [PubMed]

40. Morosan, M.; Al Hassan, M.; Naranjo, M.; Lopez-Gresa, M.P.; Vicente, O. Comparative analysis of drought responses in Phaseolus vulgaris (common bean) and P. coccineus (runner bean) cultivar. EuroBiotech J. 2017, 1, 247-252. [CrossRef]

41. Hoagland, D.; Arnon, D. The water-culture method for growing plants without soil. Circ. Califor. Agric. Exp. Stat. 1950, 347, 32-63.

42. Bates, L.S.; Waldren, R.P.; Teare, I.D. Rapid determination of free proline for water stress studies. Plant Soil 1973, 39, 205-207. [CrossRef]

43. Arteaga, S.; Al Hassan, M.; Wijesinghe, C.; Yabor, L.; Llinares, J.; Boscaiu, M.; Vicente, O. Screening for Salt Tolerance in Four Local Varieties of Phaseolus lunatus from Spain. Agriculture 2018, 8, 201. [CrossRef] 
44. Andrade, E.; Ribeiro, V.; Azvedo, C.; Chiorato, A.; Williams, T.; Carbonell, S. Biochemical indicators of drought tolerance in the common bean (Phaseolus vulgaris L.). Euphytica 2016, 210, 277-289. [CrossRef]

45. Bacha, H.; Tekaya, M.; Drine, S.; Guasami, F.; Touil, L.; Enneb, H.; Triki, T.; Cheour, F.; Ferchichi, A. Impact of salt stress on morpho-physiological and biochemical parameters of Solanum lycopersicum cv. Microtom leaves. S. Afr. J. Bot. 2017, 108, 364-369. [CrossRef]

46. Sen, A.; Ozturk, I.; Yaycili, O.; Alikamanoglu, S. Drought tolerance in irradiated wheat studied by genetic and biochemical markers. J. Plant Growth Regul. 2017, 36, 669-676. [CrossRef]

47. Koźmińska, A.; Wiszniewska, A.; Hanus-Fajerska, E.; Boscaiu, M.; Al Hassan, M.; Halecki, W.; Vicente, O. Identification of salt and drought biochemical stress markers in several Silene vulgaris populations. Sustainability 2019, 11, 800. [CrossRef]

48. Verbruggen, N.; Hermans, C. Proline accumulation in plants: A review. Amino Acids 2008, 35, 753-759. [CrossRef]

49. Grigore, M.N.; Boscaiu, M.; Vicente, O. Assessment of the relevance of osmolyte biosynthesis for salt tolerance of halophytes under natural conditions. Eur. J. Plant Sci. Biotechnol. 2011, 5, 12-19.

50. Parvaiz, A.S.; Satyawati, S. Salt stress and phyto-biochemical responses of plants-A review. Plant Soil Environ. 2008, 54, 89-99. [CrossRef]

51. Hayat, S.; Hayat, Q.; Alyemeni, M.N.; Wani, A.S.; Pichtel, J.; Ahmad, A. Role of proline under changing environments: A review. Plant Signal. Behav. 2012, 7, 1456-1466. [CrossRef]

52. Rana, V.; Ram, S.; Nehra, K. Proline biosynthesis and its role in abiotic stress. Int. J. Agric. Res. Innov. Technol. 2017, 6 .

53. Kavi Kishor, P.; Sreenivasulu, N. Is proline accumulation per se correlated with stress tolerance or is proline homeostasis a more critical issue? Plant Cell Environ. 2014, 37, 300-311. [CrossRef] [PubMed]

54. Al Hassan, M.; López-Gresa, M.P.; Boscaiu, M.; Vicente, O. Stress tolerance mechanisms in Juncus: Responses to salinity and drought in three Juncus species adapted to different natural environments. Funct. Plant Biol. 2016, 43, 949-960. [CrossRef]

55. Al Hassan, M.; Pacurar, A.; López-Gresa, M.P.; Donat-Torres, M.; Llinares, J.; Boscaiu, M.; Vicente, O. Effects of salt stress on three ecologically distinct Plantago species. PLoS ONE 2016, 11, e0160236. [CrossRef]

56. Plazas, M.; Nguyen, H.; González-Orenga, S.; Fita, A.; Vicente, O.; Prohens, J.; Boscaiu, M. Comparative analysis of the responses to water stress in eggplant (Solanum melongena) cultivars. Plant Physiol. Biochem. 2019, 143, 72-82. [CrossRef]

57. Chen, Z.; Cuin, T.; Zhou, M.; Twomei, A.; Naidu, B.; Shabala, S. Compatible solute accumulation and stress-mitigating effects in barley genotypes contrasting in their salt tolerance. J. Exp. Bot. 2007, 58, 4245-4255. [CrossRef]

58. Koźmińska, A.; Al Hassan, M.; Hanus-Fajerska, E.; Naranjo, M.A.; Vicente, O.; Boscaiu, M. Comparative analysis of water deficit and salt tolerance mechanisms in Silene. S. Afr. J. Bot. 2018, 117, 193-206. [CrossRef]

59. Nagesh, B.; Devaraj, V. High temperature and salt stress response in French bean (Phaseolus vulgaris). Austr. J. Crop Sci. 2008, 2, 40-42.

60. Ashraf, M.; Iram, A. Drought stress induced changes in some organic substances in nodules and other plant parts of two potential legumes differing in salt tolerance. Flora 2005, 200, 535-546. [CrossRef]

61. Rosales, M.A.; Ocampo, O.; Rodríguez-Valentín, R.; Olvera-Carrillo, Y.; Acosta-Gallegos, J.; Covarrubias, A.A. Physiological analysis of common bean (Phaseolus vulgaris L.) cultivars uncovers characteristics related to terminal drought resistance. Plant Physiol. Biochem. 2012, 56, 24-34. [CrossRef] [PubMed]

62. Sánchez, E.; Ruiz, J.M.; López-Lefebre, L.R.; Rivero, R.M.; García, P.C.; Romero, L. Proline metabolism in response to highest nitrogen dosages in green bean plants (Phaseolus vulgaris L. cv Strike). J. Plant Physiol. 2001, 158, 593-598.

63. Mackay, C.E.; Hall, C.; Hofstra, G.; Fletcher, R.A. Uniconazole-induced changes in abscisic acid, total amino acids, and proline in Phaseolus vulgaris. Pestic. Biochem. Phys. 1990, 37, 74-82. [CrossRef]

64. Zengin, F.K.; Munzuroglu, O. Effects of some heavy metals on content of chlorophyll, proline and some antioxidant chemicals in bean (Phaseolus vulgaris L.) seedlings. Acta Biol. Cracov. Bot. 2005, 47, 157-164.

65. Abdelhamid, M.T.; Rady, M.M.; Osman, A.S.; Abdalla, M.A. Exogenous application of proline alleviates salt-induced oxidative stress in Phaseolus vulgaris L. plants. J. Hortic. Sci. Biotech. 2013, 88, 439-446. [CrossRef]

66. Domínguez, A.; Yunel Pérez, Y.; Alemán, S.; Sosa, M.; Fuentes, L.; Darias, R.; Demey, J.; Rea, R.; Sosa, D. Respuesta de cultivares de Phaseolus vulgaris L. al estrés por sequía. Biot. Veg. 2014, 14, 29-36. 
67. Gürel, F.; Öztürk, Z.N.; Uçarlı, C.; Rosellini, D. Barley genes as tools to confer abiotic stress tolerance in crops. Front Plant Sci. 2016, 7, 1137. [CrossRef]

68. Yoshida, J.; Tomooka, N.; Khaing, T.Y.; Sunil Shantha, P.G.; Naito, H.; Matsuda, Y.; Ehara, H. Unique responses of three highly salt-tolerant wild Vigna species against salt stress. Plant Prod. Sci. 2020, 23, 114-128. [CrossRef] 